ББК: 85.101 .1

DOI: $10.18688 /$ aa2111-08-60

T. S. Yurieva, E. Iu. Staniukovich-Denisova, G. Yu. Ershov

\title{
Curatorial Approaches at the Diaghilev Museum of Contemporary Art at St. Petersburg State University: Representations of Art in Synchronous and Diachronic Aspects $^{1}$
}

Since the late 1980s, along with the radical transformations in the country, a new period in the history of museum practice has begun in Russia, raising the issue of recognition and museification of contemporary and independent art. This period is associated with the processes of integration of the Russian art into the world culture and scientific exchange with foreign specialists, as well as the creation of the art market. General commercialization (including the desire to sell the protest art more dearly) went side by side with romantic ideals.

In Russia, Anastasia Karlova notes, "the phenomenon of the international art world has emerged in the 1990s, which was facilitated by the widespread distribution of the biennale, the appearance of new art centres, and the increased mobility of artists and curators" [10]. The National Centre for Contemporary Arts in Moscow (1992) has appeared during those years. In the Russian Museum, the Department of the Newest Trends was created in the late 1980s. The main task of the department was the consolidation of new non-traditional types of art, new media, and technologies, such as installations, assemblages, video art, photography, and photo-based art. The successful museum experiments of acquisition, scientific study, and representation of international contemporary art collections begun within the framework of the Tretyakov Gallery, the Russian Museum, and the Hermitage [1;2]. The Manege Central Exhibition Hall was instructed by the Board of Culture of the city government to found the collection of works of Leningrad artists with the aim of creating the Museum of Modern Art in St. Petersburg.

This article traces the development of curatorship and the representation of art in synchronous and diachronic aspects on the example of the history of the Diaghilev Museum of Contemporary Art at St. Petersburg State University. Its origins were laid by the activities and collection of the "Diaghilev Art Centre", a non-profit cultural organization, established in 1990 "for the purpose of preserving, creating, distributing, and mastering cultural values both in Russia and abroad, for the revival of the traditions of S. Diaghilev and the support and promotion of all forms of national culture within the country and abroad". The name and artistic aspirations

The publication was prepared within the framework of the research work of St. Petersburg State University "HUM_2020 - 2 Curatorial practices and strategies: new opportunities for the representation of contemporary art: 2021", project ID PURE SPBU 53363805. 
of Sergei Diaghilev ${ }^{2}$, a graduate of the Faculty of Law of St. Petersburg University, a brilliant curator and producer of grandiose projects (first of all, the "Russian Seasons") determined the direction of the development of the art-centre and the museum for the next 30 years.

\section{History: Diaghilev Art Centre}

In September 1990, the idea of creating Diaghilev Art Centre was realized by Tatiana Semenovna Yurieva (1943-2021), an art critic and an Americanist, who had previously taught the history of art and criticism at the St. Petersburg Academy of Arts for about 20 years. During that transitional period of changes in the political system and legislation of our country, the legal registration of new forms of cultural institutions did not always accurately reflect their actual functioning in time and was oftenly delayed. The founding agreement of Diaghilev Art Centre (10.01.1994), created by the "Chas Pik" publishing house and Elena Lyarskaya, Tatiana Yurieva, and Yury Novikov, have been preserved. The main activities of the Centre were stated as follows: "museum practice and collecting; organization and holding of exhibitions, festivals, fairs, and auctions with the demonstration and sale of works of art, folk crafts, and antiques; production, replication and sale, including through a network of branded shops, of works of fine and decorative arts, folk crafts, as well as antiques; conducting art history, theater, literary, and artistic seminars, symposiums, and conferences; creation and operation of creative workshops and clubs; exchange of delegations and specialists in the field of culture and art".

In S. Diaghilev's footsteps [18, pp. 5-12], but during another critical epoch, T. Yurieva, the general director of the centre, became one of the first Russian curators of a new type. She was, as described by Adrian George, connecting different worlds, collecting works of art around artistic or historical themes or uniting groups of artists [9]. The Centre's projects were to eliminate the severed cultural ties between Russia and Western countries (especially the Russian Expatriates), between the contemporary art (1980-1990s) and the art of the Russian Silver Age and the Avant-garde (the first third of the $20^{\text {th }}$ century). The Diaghilev Art Centre organized dozens of exhibitions of Leningrad nonconformists, both collective and personal, in St. Petersburg $^{3}$, Moscow, and abroad, discovering new names in the contemporary art world. The socalled Diaghilev Circle included more than 50 artists, recognized today as the gurus of Russian contemporary art (Zaven Arshakuni, Gleb Bogomolov, Levon Lazarev, Vyacheslav Mikhailov, Valery Lukka, Vladimir Ovchinnikov, Evgeny Ukhnalev, Felix Volosenkov, etc.).

Continuing the tradition of exhibitions of the $19^{\text {th }}$-century Peredvizhniki group and Diaghilev's Seasons, the Centre organized an exposition of works by St. Petersburg artists on board the sailing ship "Mir", which sailed as part of the 'Cutty Sark Tall Ships' Races' international regatta

\footnotetext{
2 In a letter to Alexander Benois, Sergei Diaghilev defined his mission as follows: "I want to nourish Russian painting, clean it up and, most importantly, bring it to the West, exalt it in the West ..." May 24, 1897 [6, p. 416]. About the S. Diaghilev's ideas of museum design and exhibiting see [12].

3 Some large-scale collective exhibitions organized by the Diaghilev Center at various exhibition venues, including the Marble Palace, the Tavrichesky Palace, the Manege Central Exhibition Hall: "Soviet-American Exhibition of Graphics" (1990), "Makhmadim - Contemporary Jewish Art of St. Petersburg" (1991), "My Friends are Heroes of Myths"(1993), "Diaghilev Centre Presents "(1993), "Portraits of Russian Culture Figures" (1997), exhibitions of art groups" Sterligov's School", "Kochevye", "Noopark", "Old Town", "Neoacademism", dozens of opened monthly exhibitions of St. Petersburg nonconformist, foreign and of the Russian Abroad artists [18].
} 
of 1998-1999. During the stops of the sailboat, the European viewer could be acquainted with the modern art of St. Petersburg and communicate with its creators. The exhibition projects were followed by lectures, often acquiring a broader conference format ${ }^{4}$. The documentary series 'Sergei Diaghilev's World of Art' was filmed in 2007 (script by T. Yurieva, Oasis TV Studio commissioned by GTRK Kultura), a memorial plaque was installed on the house where S. Diaghilev lived in 1997, and, in 2003, the monument to Diaghilev was erected in Paris (L. Lazarev) [18, pp. 13-14].

The first legal address of the Diaghilev Centre was at Mikhailovsky Castle (Sadovaya St., 2), the premises of which had been given to the Russian Museum in 1991 and then gradually restored. The headquarters of the Centre was located in the Marble Palace, where the V.I. Lenin Museum was reformed at that time, and then on Pushkinskaya St., 10, cooperating with the famous Free Culture Partnership. The huge layer of a completely new content that was opened to the viewer did not require special interpretation and representation yet, and the curatorship was carried out not so much in relation to individual exhibition projects, but in supporting, promoting the artists themselves, and uniting them around the idea of the diversity and uniqueness of Russian culture.

By the first decade of the $21^{\text {st }}$ century, the rise of carbon fuel market has ensured the rapid growth of contemporary art and the inclusion of Russia in the transnational art process. The actualization of contemporary art in the context of a classical museum, popular in the West, has become fashionable in Russia [2, p. 63]. There was a broad discussion about the need to create a Museum of Contemporary Art in Russia and the representation of contemporary art in synchronous and diachronic aspects. This would be impossible without the soil created and cultivated by the labor of several generations - "and the foresight and stubbornness of nonconformists, and the enthusiasm of curators and critics of the 1980s and early 1990s, who rushed headlong into the waves of the contemporary" [3, pp. 8-9].

Several contemporary art museums, such as the Garage Museum of Contemporary Art (Moscow, 2008), Erarta Museum (St. Petersburg, 2009), Novy Museum (St. Petersburg, 2010), etc, have been opened on a private initiative. In 2007, the Department of Contemporary Art of the State Hermitage Museum (2007), have been officially established during that decade.

The documents from the funds of the Diaghilev Museum of Contemporary Art (signed agreement of intent) indicate that the issue of creating the museum was discussed and agreed upon with Sergey Bogdanov, then the Dean of the Philology and Arts Department, back in early 1999. The permanent exhibition (!) of the museum was allocated in one of the auditoriums and a former shooting gallery in one of the university buildings (NIFI). By 2001, the Diaghilev Centre received accommodation at the Philology Department located on the Lieutenant Schmidt embankment, 11/2. It was an oval Blue living room (approx. 100 sq.m.) in the centre of the building on the first floor, with windows facing the Neva River. This room is still the main exhibition hall of the museum; its historical decoration with rich stucco is covered with museum billboards. The permanent exhibition has not found its place yet, and

\footnotetext{
4 Art projects, exhibitions, and conferences: "Dialogues of Artists" (2001-2003), "Artists against AIDS" (2005), "Improvisations. The Tale of Igor's Campaign" (2006), "Semantics of Painting" (2007), "Baltic Biennials" (since 2005 to the present), and others. About the exhibition culture of St. Petersburg in early 2000s see more [13].
} 
the museum exhibits are located in a specially equipped modern University storage facility in Peterhoff.

Despite the fact that the activities of the Diaghilev Centre have been carried out at Saint-Petersburg State University since 1999 and that its director T.S. Yurieva received the position of university Professor at the Faculty of Liberal Arts and Sciences, the process of official state registration of the museum was delayed for many years.

Since 2008, the art collection of the Centre was gradually transferred to the university, and the Centre itself was transformed into a museum. Those changes entailed the proposal of the development of the new type of a museum, which would have a special joint creativity program for teachers and students. The museum collection, according to its director, is a small model of the world which helps a person to navigate, adapt to reality, and solve not only scientific problems, but also philosophical ones. The life of the Diaghilev Museum of Contemporary Art at the University is about the present, but it is constantly turned towards the future. Such a museum is unique for Russia, for it carries not just a university and educational status, but also has a constantly replenished collection of modern art, thanks to the authority of the university and the creators of the museum. Its expertise, as well as the immediate prospects, is important not only for the museum practice, the analysis of the condition of modern domestic and foreign art, but above all, for understanding the socio-cultural situation in which we all find ourselves. The museum is a unique platform for scientific experiments and research based not only on exhibition material, but also on conferences regularly held by the museum together with the Faculty of Liberal Arts and Sciences at St. Petersburg State University.

\section{University Museum of Contemporary Art today}

Since 2008, the Museum ${ }^{5}$ has acquired its present name [11]. But, only in 2017, the universities, as scientific and educational institutions, received the legal right to carry out museum activities as well.

The exhibition and conference projects ${ }^{6}$ were combined with museum functions to acquire, conserve, research, communicate, and exhibit the heritage for the purposes of education, study and enjoyment (ICOM, 2007) $)^{7}$.

The "Covid-19" pandemic, which had started for the St. Petersburg museums in March 16, 2020 when the Hermitage introduced forced restrictions on the visits, generally changed the relationship of a person to the world. Most people during the pandemic, quarantine, or self-isolation regime found themselves under house arrest. The streets were deserted, reminiscent of medieval cities during the pestilence. An invisible enemy filled everything around, penetrating everyone's consciousness and filling the soul with an almost mystical horror of growing danger. Going out on the street seemed to be an exceptional, risky, and life-threatening business. The

5 A Planet of the University. Diaghilev Museum of Contemporary Art (Saint-Petersburg University Media Center, 2021) Available at: https://www.youtube.com/watch?v=ilQWhyilJqs

6 "Culture of the Russian Abroad 1990-2000" (2013); "Terror and Culture" (2014); Baltic Biennials I - IV (since 2005); "Known and Unknown Discoveries of the $20^{\text {th }}$ Century" (2013); "Ruin, Fragment, Crystal: About the Whole and the Unified in Modern Theory and Practice of Art" (2015); "China - Russia - the USA. Three Poles of a Multipolar World" (2016-2019); "The Muses of Hong Kong” (2018); Exhibition of Contemporary Chinese Art "From Generation to Generation" (2019) [15]; "Amanita Festival” (2019).

7 See also [4]. 
world, rapidly unfolding, transparent, and open, had collapsed and shrunk, breaking up into many fractions. The new pandemic time coincided with the narrowing of space. Space has flowed into time.

The curatorial strategies inevitably had to change also, which lead to new communicative and artistic practices. Exhibitions of the last two years ("Ales Lyalyush. Top view. Unreal stories. Digital painting, objects", "Vladislav Mamychev Monroe - Sveta Ostrova. Star Wars", exhibitions by Valery Lukka "Imaginary Horizon Line", Sergey Kovalsky "Social Folklore", Pavel Mikhailov "Artifacts", etc) received their virtual continuation (https://izi.travel/ru or https:// artefact.culture.ru/), first as the only way allowed, then as an additional mechanism.

As Violetta Evallyo notes, in isolation from the material environment, a virtual museum can be considered as a complex art object. Its key features are media integration, variability of communication modes, manipulation of objects, and, in some cases, increased conceptuality [8] (see also [14]).

The key project of the last year was the 'Solitude' exhibition ${ }^{10}$ (rus. - Udeninenie) [19], which was organized by the Diaghilev Museum on the site of the exhibition hall of the Novy Museum in December $2020^{11}$.

The "Solitude" exhibition (photography, sculpture, graphics, video) addresses the experience of this new human interaction with the world during the period of self-isolation. Photos, dancing on the verge of "dream-reality", allow us to show the feelings and experiences that have become the content of most people's lives lately. These are observations made by an alienated, otherworldly view. Therefore, the main character of most of the pictures is existential emptiness filled with fear, longing, and anxiety. The phenomenon of emptiness is an indisputable prerogative of photography. Time "Covid-19" once again confirmed the true nature of photography, capable of grasping the absence and emptiness, which are necessary conditions for the perception of things in space and time.

The central media exhibit was a film where the works of the exhibition were animated in the realm of a typical modern Russian city residential area. "Solitude 2" was created in the form of a quest ${ }^{12}$ : a frightened lonely resident goes out into the street from his apartment, confused about the reality.

For many people, a window has become a kind of camera lens, which day after day registers what is happening, where the sharpened vision rediscovers familiar things. Of course, the nature of the vision during self-isolation was conditioned by informational background being

\footnotetext{
8 Ales Lyalush's digital paintings on the basis of goggle maps show changing, alive and pulsating images of modern cities. Curator Alexey Lovtsov. Available at: https://www.youtube.com/watch?v=HAH21wBpLSE (in Russian).

9 A disco style exhibition presents an early cosplay photo session of V. Mamyshev-Monroe (2005). Curators Andrey Khlobystin, Svetlana Ostrova. Available at: https://www.youtube.com/watch?v=-S_MLHuVbYU (in Russian).

10 Curators Gleb Ershov and Tatiana Yurieva. Available at: https://www.youtube.com/watch?v=gVMradplszo (in Russian).

11 An attempt to show this exhibition in an expanded form in the exhibition hall of Saint-Petersburg State University in the building of the Twelve Colleges in the fall of 2021 during the International Cultural Forum failed due to the cancellation of the forum itself due to the epidemic situation in the world.

12 Wandering simulator 3d/art game/vr (design and programme developers Dmitry Rotkin, Ekaterina Mikhatova, Aleksandr Tsikarishvili). Available at: https://app.lapentor.com/sphere/vystavka-uedinenie
} 
pumped up, and its emerging forms were also an attempt to resist preventive control and discipline measures. The artist is not too susceptible to the conjuncture of time in the sense that, in general, he does the same as always. Time, however, sets the necessary focus, allowing the features of his artistic optics to open more clearly. Simple things and conditions during the pandemic were filled with new meaning and drama. Photography, being somewhere in the middle between documentary evidence and artistic speculation, allows its duality to combine the objective and subjective principles.

Yury Molodkovets (photographer at the State Hermitage Museum) showed a museum sculpture covered with a plastic film as a cocoon or shroud, forming an 'untouchable' space around. The director of the Hermitage, Mikhail Piotrovsky, poetically compared them to the "wrapped up" from the Koran (suras 73, 74).

Alexander Verevkin in the project "Topography of Emptiness" (2017-2020) worked with a depopulated urban landscape, in which the all-seeing eye of a video surveillance camera is present in the depth of the frame. The pandemic time has brought an additional feeling of anxiety, lurking danger, and the invisible presence of a potentially deadly threat.

Igor Bryakilev created his interior photos using a pinhole camera. The square format of the pictures balances the already frozen flow of life in the frame, where a person barely appears as a ghostly, murky shadow, leaving room only for light coming through the window. In the photographs, the technique of reflection is used - in a mirror, window, reflections, and overlays of plans, which brings a feeling of flickering duality - a phantom staying simultaneously in different space and time environments.

Dmitry Goryachev is represented by the photographs taken in the reporter's genre. Defying the prohibitions with passion, day after day, he tracked the pandemic of fear that gripped the city. The disciplined population, in the horror of stupor, voluntarily hid in their own interiors. It is worth saying that, left alone by itself, St. Petersburg, by all accounts, has won a lot - it could appear as such an architectural whole on an ancient veduta. At the same time, the artist "registed the absurdity of decisions that, according to the officials, were supposed to save the townspeople from misfortune. Sometimes it even seemed that conceptual artists were working on the "design" of the city. Take, for example, swings wrapped around with "antiviral" signal tapes on playgrounds, or the 'Iskustv' Square entangled with the same tapes..." [19].

Photos and videos are what has become for many self-isolated people the only window to the world and a reason to communicate in social networks. Photos for the exhibition in the form of screenshots posted by Alexander Terebenin ${ }^{13}$ in the Facebook feed during the general home sitting focused attention on topics discussed by the network audience, and thereby gained event status.

Alexey Borisov solved the problem of representation of disconnection during self-isolation by capturing a video link image on the smartphone screen. Dialog boxes seem to represent double portraits, with their diversity referring to hierarchical images on the stamps of icons and reliefs. Visualized mobile communication with the interlocutor, partly reminds us of the Sacra Conversazione motive. In this series, the author is present everywhere, like a medium

13 Alexander Terebenin (1959-2021) died in mid-June 2021. He, according to his usual practice, was filming in an abandoned building, fell through and was seriously injured, it was not possible to save him. 
connecting everyone into one field of communication. The virtual style of communication is a new reality of our time: here the technical capabilities of video communication coincided with the preventive conditions of the pandemic. Dialog boxes open the isolation of the interlocutor into an interaction zone, where everyone brings a microcosm into the general field of conversation. The phenomenon of equality is also important, since the speaker can always rebuild the scale by changing the hierarchy of scales.

The painted relief collage by Leonid Tskhe "The Horseman" (an awkward figure with closed eyes on a racing horse) is the semantic tuning point of the entire exhibition. After all, what but flight and self-exile from the world was associated during the pandemic with solitude and falling out of the real course of time and space that occur to us in a dream.

The year 2021 has become a time of emerging from this dream into a new reality, taking into account the pandemic and remote feeding. Our approaches have changed and the new requirements have developed, as the new generation of curators and museum workers still emerges. The ongoing changes require discussions and evaluations ${ }^{14}$. To define new museum strategies, discussion platforms organized within the framework of the St. Petersburg State University 2018-2021 project play an important role: "Curatorial Practices and Strategies of Professional Training in Contemporary Art Criticism" [7; 16], "The Challenge of Civilization" (exhibition and Round Table on Covid-19 (2020), the planned Round Table "Curatorial Practices and Strategies: New Opportunities for the Representation of Art in Synchronous and Diachronic Aspects" (2021-22). The results of these discussions allow us to trace curatorial strategies on the latest material both in relation to contemporary art and in relation to the "historical". The museums, as "institutions of memory", which preserve social practices and physical evidence of human experience in general [4], address the issues acutely posed by the reality in recent times (especially the not fully meaningful pandemic), with the aim of introducing the concept of inclusiveness of museums in general.

Since 2021, the university has become a member of the Union of Russian museums. This opens up the new prospects for the Diaghilev Moscow Art Institute and other museums (historical and scientific) within the university. Since St. Petersburg, for well-known reasons, is very rich in world-class art collections and has a unique urban art culture, the connection between the collections of museums of various types, as well as the principles of education of art historians and curators, still remains an important topic that gives great prospects for both the university ${ }^{15}$ and the museum.

\section{References}

1. Biryukova M. The Current State of Culture in Russia as Reflected in the Art, Museum, Exhibition Sphere. Fillis C. (ed.). A Closer Look at Russia and Its Influence in the World. New York, Nova Science Publishers, Inc., 2019, pp. 157-173.

14 On the recent experience of art mediation in St. Petersburg see [17].

15 Here, among other things, the positive experience of university museums in Italy can be taken into account [5]. 
2. Biryukova M. V. Modern and Contemporary Art in the Russian Museum Context. Muzeologia a Kulturne Dedicstvo, 2020, vol. 8, no. 3, pp. 63-74.

3. Borovsky A.D. Between the Festival and the Dole. Borovsky A.D. Prakticheski ne iziashchnyye iskusstva (Practically Not Fine Arts). Moscow; St. Petersburg, Palmira Publ., 2020, pp. 7-36 (in Russian).

4. Bruni I. "Selective memory": A Museum and Its Past. Actual Problems of Theory and History of Art: Collection of Articles, vol. 12. St. Petersburg, Saint-Petersburg University Press Publ.; Moscow, Lomonosov Moscow State University, 2022. (in press).

5. Corradini E. Perspectives of Sustainable Development for the Italian University Museum. Actual Problems of Theory and History of Art: Collection of Articles, vol. 12. St. Petersburg, Saint-Petersburg University Press Publ.; Moscow, Lomonosov Moscow State University, 2022. (in press).

6. Doronchenkov I. A. On the Modernist Frontier: Foreign Art Exhibitions in Russia in the 1890s. Actual Problems of Theory and History of Art: Collection of Articles, vol. 10. Lomonosov Moscow State University; St. Petersburg, NP-Print Publ., 2020, pp. 413-422 (in Russian). https://doi.org/10.18688/aa200-3-36

7. Ershov G. Yu. Curatorial Strategies in Saint-Petersburg Contemporary Art. Some Examples. Vestnik of Saint Petersburg State University. Arts, 2020, vol. 10, no. 3, pp. 419-434 (in Russian). https://doi.org/10.21638/ spbu15.2020.303

8. Evallyo V. Museums Online. Salnikova E.; Evallyo V.; Novikova A. (eds.). Iskusstvo v kontekste pandemii: mediatizatsiia i diskurs katastrofizma (Art in the Context of a Pandemic: Mediatization and the Discourse of Catastrophism). Izdatelskie resheniia Publ., 2020, pp. 476-498 (in Russian).

9. George A. The Curator's Handbook. Museums, Commercial Galleries, Independent Spaces. London, Thames and Hudson Publ., 2015. 320 p.

10. Karlova A. I. Museum of Contemporary Art in Soviet and Russian Culture. Vestnik of Saint Petersburg University. Series 6, 2009, no. 4, pp. 131-136 (in Russian).

11. Kupina Ju. A. (ed.). Kollektsiia znanii. Muzei i kollektsii Sankt-Peterburgskogo gosudarstvennogo universiteta (Collection of Knowledge. Museums and Collections of Saint-Petersburg State University). St. Petersburg, St. Petersburg University Press, 2018. 288 p. (in Russian).

12. Luchkin A. V. The S. P. Diaghilev's Views for Museum Design. Triumf muzeya? (A Triumph of A Museum?). St. Petersburg, 2005, pp. 304-309 (in Russian).

13. Lyashko A. V. The Exhibition Culture of St. Petersburg: Trends in Contemporary Art Life. Triumf muzeia? (A Triumph of A Museum?). St. Petersburg, 2005, pp. 226-243 (in Russian).

14. Novikova A. A. Museums and Their Virtual Extensions: Convergence against the Background of Quarantine. Iskusstvo v kontekste pandemii: mediatizatsiia i diskurs katastrofizma (Art in the Context of a Pandemic: Mediatization and the Discourse of Catastrophism). Izdatelskie resheniia Publ., 2020, pp. 456-475 (in Russian).

15. Peng F.; Yurieva T. S.; Tulchinskii G. L.; Staniukovich-Denisova E. Iu. The Processes of Contemporary Art in China and the Russian-Chinese University Humanities Project in St. Petersburg (2016-2017). Vestnik of Saint Petersburg State University. Arts, 2017, vol. 7, no. 4, pp. 423-435. https://doi.org/10.21638/11701/ spbu15.2017.404

16. Sasonko K. 'Gallery vs Curator'- Discussion of Scientific Conference 'Curatorial Practices'. Novoe iskusstvoznanie (New Art Studies), 2021, no. 4, pp. 112-115 (in Russian).

17. Venkova A. Art Mediation: Philosophy, Aesthetics, and Practice Actual Problems of Theory and History of Art: Collection of Articles, vol. 11. St. Petersburg, Saint-Petersburg University Press Publ.; Moscow, Lomonosov Moscow State University, 2021, pp. 819-829 (in Russian).

18. Yurieva T. S. (comp.). Nash dar Sankt-Peterburgskomu gosudarstvennomu universitetu (Our Gift to St. Petersburg State University). St. Petersburg, 1997. 163 p. (in Russian).

19. Yurieva T.; Ershov G. (comp.). Uedinenie. Sovremennye peterburgskie khudozhniki o vremeni samoizoliatsii $i$ pandemii. Fotografii, skul'ptura, grafika, video (Solitude. Contemporary St. Petersburg Artists on the Time of Self-Isolation and the Pandemic). Photos, Sculpture, Graphics, Video. St. Petersburg, 2020. (in Russian).

Title. Curatorial Approaches at the Diaghilev Museum of Contemporary Art at Saint- Petersburg State University: Representations of Art in Synchronous and Diachronic Aspects

Authors. Yurieva, Tatiana Semenovna (1934-2021) - full doctor, professor. St. Petersburg State University. Universitetskaya nab., 7-9, 199034 St. Petersburg, Russian Federation. 
Staniukovich-Denisova, Ekaterina Iurievna - senior researcher. Research Institute of the Theory and History of Architecture and Town Planning (branch of the Central Institute for Research and Design of the Ministry of Construction of Russian), Dushinskaia ul., 9, 111024 Moscow, Russian Federation; head lecturer. St. Petersburg State University, Universitetskaya nab., 7-9, 199034 St. Petersburg, Russian Federation. e.stanyukovich-denisova@spbu.ru ORCID: 0000-0002-5602-658X

Ershov, Gleb Yurievich - Ph. D., associate professor. St. Petersburg State University. Universitetskaya nab., 7-9, 199034 St. Petersburg, Russian Federation. gleb.ershov@gmail.com ORCID: 0000-0003-0397-4882

Abstract. The article considers the development of curatorial activity and the representation of art in synchronous and diachronic aspects, as well as the reveal of the uniqueness of the first university museum of modern art in Russia. The museum of contemporary art named after S. P. Diaghilev was founded in 2008 based on the Diaghilev Art Centre (1990-2008); currently, it is part of the Exhibits and Collections Management of St. Petersburg University. The paper carries out the comparative analysis of curatorial practices and curatorial strategies used in the organization of cultural events and exhibitions of the museum in different periods. The museum, from the stage of its creation in the 1990s as an art center to the present, is considered in the context of the general idea of establishing museums of contemporary art in Moscow and St. Petersburg. Special attention has been paid to the museum's activities and projects of recent years, with regard to the new realities of the pandemic, self-isolation, and remote communication.

Keywords: university museum, museum of modern art, curatorship, pandemic, self-isolation, contemporary art, exhibitions, remote communication

Название статьи. Кураторские подходы в Музее современных искусств имени С. П. Дягилева СПбГУ: репрезентации искусства в синхронном и диахроническом аспектах ${ }^{16}$

Сведения об авторах. Юрьева Татьяна Семеновна (1943-2021) - доктор искусствоведения, профессор. Санкт-Петербургский государственный университет, Университетская наб., 7-9, Санкт-Петербург, Российская Федерация, 199034.

Станюкович-Денисова Екатерина Юрьевна - старший научный сотрудник. Филиал ФГБУ «ЦНИИП Минстроя России» Научно-исследовательский институт теории и истории архитектуры и градостроительства (НИИТИАГ), ул. Душинская, д. 9, Москва, Российская Федерация, 111024; старший преподаватель. Санкт-Петербургский государственный университет, Университетская наб., 7-9, Санкт-Петербург, Российская Федерация, 199034. e.stanyukovich-denisova@spbu.ru ORCID: 0000-0002-5602-658X

Ершов Глеб Юрьевич - кандидат искусствоведения, доцент. Санкт-Петербургский государственный университет, Университетская наб., 7-9, Санкт-Петербург, Российская Федерация, 199034. gleb. ershov@gmail.com ORCID: 0000-0003-0397-4882

Аннотация. Целью исследования является изучение развития кураторской деятельности и репрезентации искусства в синхронном и диахроническом аспектах, а также выявление своеобразия опыта первого в России университетского музея современного искусства - МСИ им. С.П. Дягилева СПбГУ. Он был основан в 2008 г. на базе Центра искусств им. Дягилева (1990-2008) и сегодня входит в состав Управления экспозиций и коллекций Санкт-Петербургского университета. Проводится сравнительный анализ кураторских практик и кураторских стратегий, использованных при организации культурно-выставочных мероприятий музея в разные периоды. Опыт музея, начиная с этапа формирования в 1990-е гг. в рамках центра искусств до настоящего времени, рассматривается в контексте развития идеи и создания музеев современного искусства в Москве и Петербурге. Особое внимание уделяется деятельности музея и проектам последних лет с учетом новых реалий пандемии, самоизоляции и дистанционной коммуникации.

Ключевые слова: университетский музей, музей современного искусства, кураторство, пандемия, самоизоляция, современное искусство, выставки, дистанционная коммуникация

16 Публикация подготовлена в рамках НИР СПбГУ «НUM_2020 - 2 Кураторские практики и стратегии: новые возможности репрезентации современного искусства: 2021 г.», ID проекта в системе PURE 53363805 . 